\title{
MORPHOPHYSIOLOGY AND YIELD OF LATE SEASON MAIZE INTERCROPPED WITH Urochloa IN REDUCED ROW SPACING
}

\author{
ANTONIO LUIZ-NETO-NETO ${ }^{1}$, JUSLEI FIGUEIREDO DA SILVA ${ }^{1}$, ADRIANO DOS SANTOS $^{1}$, \\ NERIANE DE SOUZA PADILHA ${ }^{1}$, PRISCILA AKEMI MAKINO ${ }^{1}$ and GESSÍ CECCON ${ }^{2}$
}

${ }^{1} U F G D$, Dourados, MS, Brasil, aln_neto@hotmail.com,jusleifigueiredo@hotmail.com, adriano.agro84@yahoo.com.br, nerianepadilha@hotmail.com,priscila_akemi17@hotmail.com

${ }^{2}$ Embrapa Agropecuária Oeste, Dourados, MS, Brasil, gessi.ceccon@embrapa.br

Revista Brasileira de Milho e Sorgo, v.12, n.3, p. 227-239, 2013

\begin{abstract}
The aim of this study was to evaluate the morphological changes and late season maize yield in two plant densities intercropped with five populations of Urochloa (syn. Brachiaria) brizantha cv. 'Marandu' in reduced row spacing for pasture formation. The experiment was established on March 1, 2012 in an Oxisol in Dourados, Mato Grosso do Sul State, Brazil. A randomized block experimental design was used with split-plots in four replications. The main plot consisted of two maize plant densities ( 5.2 and 5.7 plants $\mathrm{m}^{-2}$ ) and the subplots of five plant densities of the Urochloa $\left(0,5,10,20\right.$ and 40 plants $\left.\mathrm{m}^{-2}\right)$. The greatest plant density of maize showed a greater leaf area index and greater yield of late season maize, but did not affect the chlorophyll content of maize and the dry matter of Urochloa. Urochloa plant densities did not affect maize yield; however, densities greater than 20 plants $\mathrm{m}^{-2}$ reduced tillering and

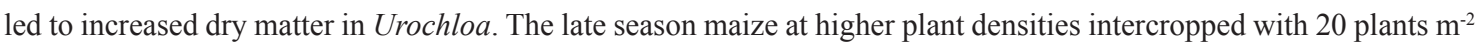
of $U$. brizantha $\mathrm{cv}$. 'Marandu' leads to total forage dry matter production and increased maize grain yield and forage for pasture formation.
\end{abstract}

Key words: Zea mays; Brachiaria; intercropping; crop-livestock integration.

\section{MORFOFISIOLOGIA E PRODUTIVIDADE DE MILHO SAFRINHA CONSORCIADO COM Urochloa EM ESPAÇAMENTO REDUZIDO}

\begin{abstract}
RESUMO - Objetivou-se, avaliar as alterações morfofisiológicas e a produtividade de milho safrinha em duas populações de plantas, consorciado com cinco populações de Urochloa (sin. Brachiaria) brizantha cv. Marandu, em espaçamento reduzido para a formação de pastagem. O experimento foi implantado em 01 de março de 2012 , em Latossolo Vermelho distroférrico, em Dourados, MS. O delineamento experimental foi em blocos casualizados, com parcelas sub-divididas em quatro repetições. A parcela principal foi constituída pelas duas populações de milho $\left(5,2\right.$ e 5,7 plantas $\left.\mathrm{m}^{-2}\right)$ e as subpacelas pelas cinco populações da forrageira $\left(0,5,10,20\right.$ e 40 plantas $\left.\mathrm{m}^{-2}\right)$. A maior população de milho proporcionou maior índice de área foliar e maior produtividade do milho safrinha, mas não interferiu no índice de clorofila do milho e na massa seca da braquiária. As populações de braquiária não interferiram na produtividade do milho, porém, populações maiores que 20 plantas $\mathrm{m}^{-2}$ promovem redução do perfilhamento e aumento de massa seca de braquiária. O milho safrinha em maior população de plantas, consorciado com 20 plantas $\mathrm{m}^{-2}$ de $U$. brizantha cv. Marandu proporciona maior produção de massa de matéria seca total, produtividade de grãos de milho e massa de matéria seca da forrageira para formação de pasto.
\end{abstract}

Palavras-chave: Zea mays; Brachiaria; consórcio; Integração Lavoura-Pecuária. 
The growing demand for food and bioenergy with greenhouse gases mitigation requires solutions to encourage socioeconomic development without compromising the sustainability of natural resources. This has stimulated the search for sustainable production systems, with intensification of land use without harming the environment, creating benefits for society. Crop-livestock integration has been indicated as an alternative for conciliating food production and environment conservation (Vilela et al., 2011).

Maize stands out for intercropping possibilities due to its greater plant height and rapid initial growth, as it is competitive with the intercropped species. Among the crops that can be intercropped beans and perennial forage (Brachiaria and Panicum genus) are highlighted (Portes et al., 2000). Maize is one of the most studied annual crops and the most adapted to cropping in integrated systems (Kluthcouski, et al., 2000; Broghi \& Crusciol, 2007; Chioderoli et al., 2010), with high quality of the forage, weed control, increase in soil organic matter, temporary immobilization of nutrients and soil protection (Borghi \& Crusciol, 2007).

Maize has been grown in the fall-winter period of late season in the Midwestern region of Brazil, soon after soybean as an important species for soil protection, especially in intercropping with a perennial forage crop such as Brachiaria or Panicum. This may contribute for a greater quantity of plant dry matter and higher percentage of covered soil, resulting in greater yields in successive crops (Ceccon et al., 2013).

Among the maize cropping modalities, reduced row spacing has been adopted by farmers, with an increase of the area and grain yield (Ceccon, 2007). Nevertheless, there are few studies for evaluation of Urochloa plant densities intercropped with maize in reduced row spacing.

The arrangement and density of plants are essential for refining appropriate use of the environment (Afférri et al. 2008), and due to the need for increasing the efficiency of light interception, hybrids were selected in plant arrangements with high densities, leading to increase in crop yield (Sangoi et al., 2002). This shows the importance of identifying Urochloa plant densities for intercropping with maize so that the two species produce in the same environment, even though maize has greater competitive capacity and suppression ability than the forage crop (Ikeda, 2010).

This study was proposed to identify morphophysiological changes and evaluate the yield of late season maize grown at two plant densities intercropped with five Urochloa plant densities in reduced row spacing aiming to pasture formation.

\section{Material and Methods}

The experiment was carried out in an experimental area in Dourados, Mato Grosso do Sul State, Brazil (22 $13^{\circ} \mathrm{S}$ and $54^{\circ} 48^{\prime} \mathrm{W}$, at $400 \mathrm{~m}$ altitude) in a very clayey texture Oxisol (Embrapa, 1999). The climate, according to the Köppen classification, is the Cwa type with hot summers and dry winters and high temperatures observed in December and January and low temperatures from May to August, similarly excessive rain in springsummer and water deficit in fall-winter (Fietz \& Fisch, 2008).

A randomized block experimental design was used in split-plots, with the main plot consisting 
of two plant densities of late season maize (5.2 and 5.7 plants $\mathrm{m}^{-2}, 52,000$ and 57,000 plants ha-1, respectively) and the subplots of five initial plant densities of $U$. brizantha cv. 'Marandu' $(0,5,10$, 20 and 40 plants $\mathrm{m}^{-2}$ ), with four replications. The experimental units consisted of 5 rows of maize at $0.45 \mathrm{~m}$ spacing between rows, of $2.25 \mathrm{~m}$ width by $12.0 \mathrm{~m}$ length, totalizing $28 \mathrm{~m}^{2}$ in each subplot.

Sowing was performed on $1^{\text {st }}$ March, 2012 in a no-till system after soybeans, using a precision pneumatic planter for maize sowing, regulated for $220 \mathrm{~kg} \mathrm{ha}^{-1}$ in the 08-20-20 NPK formula. The maize seeds (BRS 1010) were treated with thiodicarb insecticide at a rate of $0.6 \mathrm{~kg}$ a.i. 100 $\mathrm{kg}^{-1}$ of seed. Urochloa was sown mechanically on the same day and in the same rows as the maize using a pneumatic plot planter, Wintersteiger, at an average depth of $0.06 \mathrm{~m}$. The forage seeds were coated and treated with fipronil insecticide, and seeds quantity in each plot $\left(1,2,4\right.$ and $\left.8 \mathrm{~g} \mathrm{~m}^{-2}\right)$ was calculated based on the germination rate (Brasil, 2009). The sowing operation was performed separately for each species.

Ten days after emergence of the species, the maize was thinned to adjust the two plant densities; plots of one meter row were demarcated in order to evaluate the yield components and dry matter yield, only at the harvest time.

Weed control was performed by applying atrazine at a dose of $1.51 \mathrm{ha}^{-1}$ in post-emergence of the maize, forage (the emergence occurred five days after sowing for both species) and weeds. Pests were controlled by applying deltamethrin insecticide after maize emergence at a dose of $0.0051 \mathrm{ha}^{-1}$ according to occurrence.

In the beginning of flowering, over a sevenweek period, the total chlorophyll and chlorophyll
A index were evaluated in the middle of the leaf using the chlorophyll measuring device - Clorofilog (Falker, 2012), on a weekly basis. The dry matter of the two species was also evaluated, collecting five whole maize plants, randomized each subplot (in these plants were also measured maize leaf area with an automatic meter), and cutting the Urochloa plants within a $0.45 \mathrm{~m}^{2}(0.45 \times 1.0 \mathrm{~m})$ area. The samples of $0.5 \mathrm{~kg}$ subsamples were collected and dried in a forced circulation chamber at $60{ }^{\circ} \mathrm{C}$ until constant moisture was reached to determine DM yield of the species. Maize harvest was carried out on $27^{\text {th }}$ July, 2012 at physiological maturity (R6), cutting five plants at soil level for evaluating dry matter and grain yield was estimated from the grains harvested in $4.5 \mathrm{~m}^{2}$ in each subplot.

At maize harvest, the following evaluations were performed: plant height, ear height, stem diameter, leaf area, dry matter, a hundred grain weight and plot grain weight. The leaf area index (LAI), the crop growth rate (CGR) (with the data from dry matter at flowering and at harvest), the grain filling rate (GFR), the dry matter yield at flowering and at harvest, and grain yield, adjusted to $130 \mathrm{~g} \mathrm{~kg}^{-1}$ (13\%) moisture, were all calculated in the laboratory.

The following characteristics were evaluated in Urochloa: number and height of stems and dry matter of the plot, stems density and dry matter yield were estimated, with the evaluations being carried out at flowering and at maize harvest (the last evaluation was done in the row plot defined before).

In September 2012, a new sampling of Urochloa plants was performed in one meter length row to determine dry matter yield to evaluate the ability of the forage for establishing pasture. 
The data were subjected to analysis of variance by the $F$ test and regression test $(p<0.05)$. The plant density data of the maize were compared by the SNK test $(\mathrm{p}<0.05)$. The mean plant densities of $U$. brizantha cv. 'Marandu' are presented with the best fitting significant polynomial regression equation.

\section{Results and Discussion}

Analysis of variance showed a significant effect of maize plant densities for leaf area index, crop growth rate, grain filling rate, grain yield and dry matter at flowering; and significant effect of Urochloa plant densities on maize chlorophyll index, Urochloa stem density and Urochloa plant matter yield (Table 1, Figures 3, 4, 7 and 8). A significant interaction was observed between maize plant densities and Urochloa plant densities for maize leaf area index, growth rate, grain filling rate and maize plant matter yield at flowering and at harvest; and the greatest values were observed at the greater plant density (Figures 2, 5 and 6). The values are relatively high for the late season maize, but this may be explained by the greater availability of rain in the period (Figure 1).

A significant effect of maize plant densities was not observed, for Urochloa plant densities, maize plant height $(2.01 \mathrm{~m})$, ear height $(0.95 \mathrm{~m})$, stem diameter $(20.7 \mathrm{~mm})$, total dry matter yield at harvest (16.28 $\left.\mathrm{Mg} \mathrm{ha}^{-1}\right)$ and a hundred grain weight (35.6 g).

According to Aférri et al. (2008), there is no correlation between plant height, ear height and a hundred grain weight versus plant density, but there is for stem diameter; however that was not observed in this study, as increased the Urochloa plant density. Resende et al. (2003) affirm that such responses vary according to the climatic conditions and, therefore, there is no standard to be followed; moreover, there are also different responses for each cultivar.

The LAI was not affected by the Urochloa plant densities at the higher maize plant density,

TABLE 1. Alterations in traits of late season maize in function of its plant density in reduced row spacing, with crop mean values alone and intercropped with different plant densities of Urochloa brizantha 'Marandu' in Dourados, MS, Brazil, 2012. ${ }^{1}$

\begin{tabular}{cccccc}
\hline $\begin{array}{c}\text { Maize plant } \\
\text { density }\end{array}$ & Leaf area index ${ }^{2}$ & $\begin{array}{c}\text { Crop growth } \\
\text { rate }\end{array}$ & Rain filling rate & Grain yield & $\begin{array}{c}\text { Dry matter at } \\
\text { flowering }\end{array}$ \\
\hline plants $\mathrm{m}^{-2}$ & & $---------\mathrm{kg} \mathrm{ha}^{-1}$ dia $^{-1}--------$ & $-----------\mathrm{kg} \mathrm{ha}^{-1}$----------- \\
\hline 5.7 & $7.17 \mathrm{~A}$ & $156.73 \mathrm{~A}$ & $78.83 \mathrm{~A}$ & $6.228 \mathrm{~A}$ & 14.121 \\
5.2 & $6.31 \mathrm{~B}$ & $123.73 \mathrm{~B}$ & $71.56 \mathrm{~B}$ & $5.653 \mathrm{~B}$ & 11.360 \\
Mean value & 6.74 & 140.23 & 75.20 & 5.940 & 12.741 \\
CV (\%) & 9.24 & 10.63 & 9.49 & 9.47 & 11.40 \\
\hline
\end{tabular}

${ }^{1}$ Mean values followed by same letters in the column do not differ among themselves by the SNK test at 5\% probability. ${ }^{2}$ Leaf area index $=\mathrm{cm}^{2}$ of leaf $/ \mathrm{cm}^{2}$ of soil. 


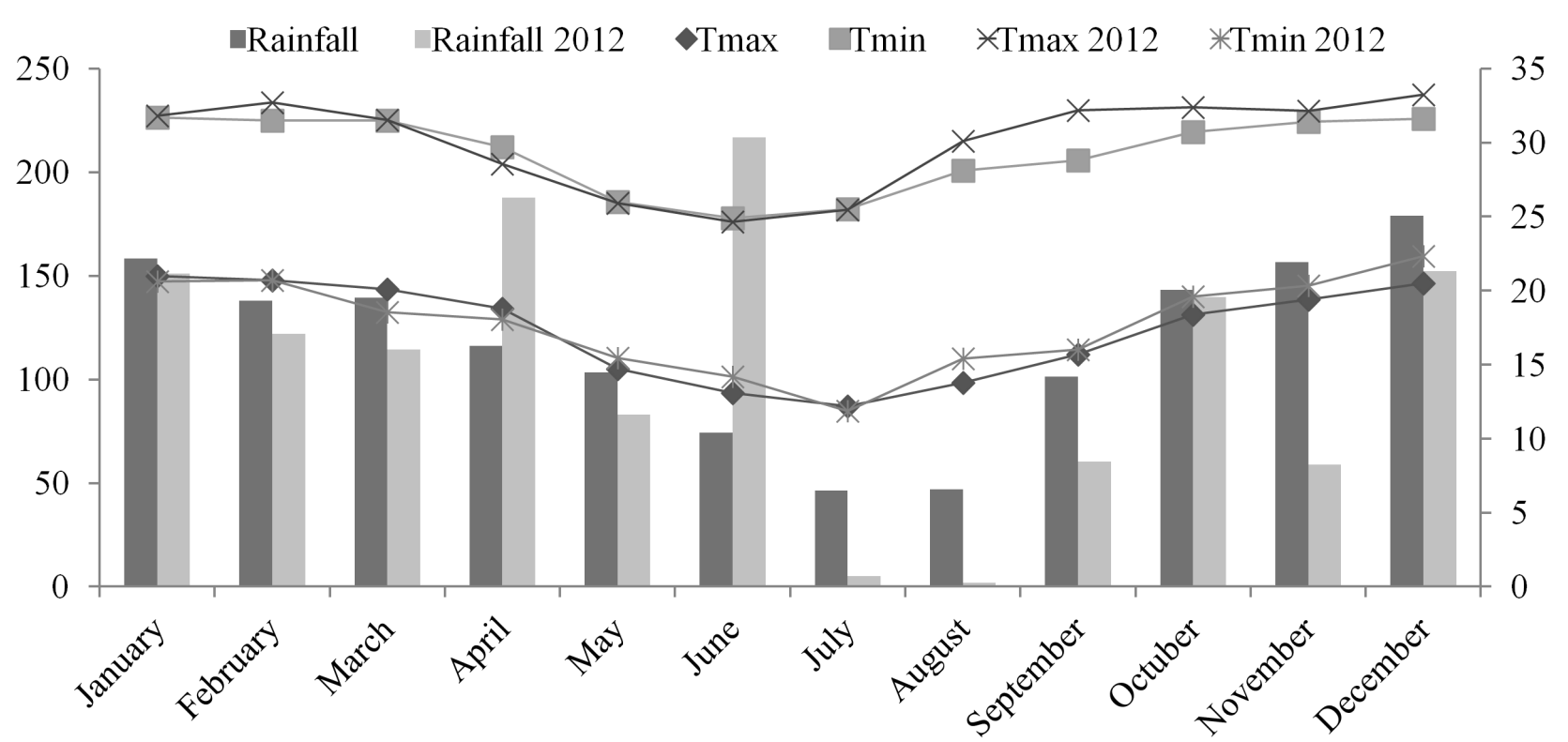

FIGURE 1. Rainfall, monthly maximum and minimum temperature in Dourados, MS, Brazil, mean over 33 years (1979 to 2012). Source: Embrapa Agropecuária Oeste. (2013).

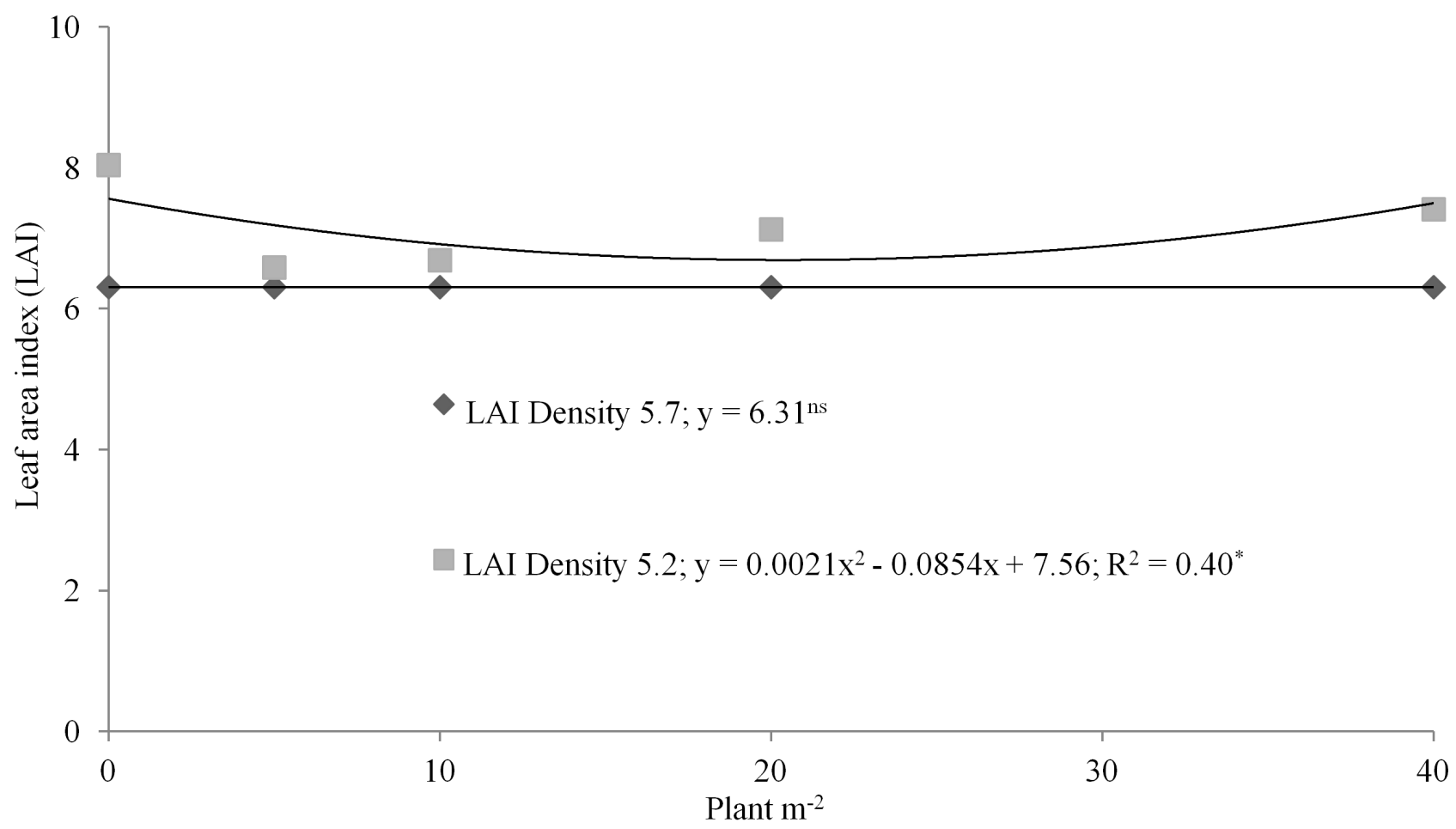

FIGURE 2. Maize leaf area index (LAI) at two plant densities (5.2 and 5.7 plants $\mathrm{m}^{-2}$ ) in intercropping with five plant densities of Urochloa brizantha 'Marandu' $\left(0,5,10,20\right.$ and 40 plants $\left.\mathrm{m}^{-2}\right)$ in Dourados, MS, Brazil, 2012. 
having shown a mean value of $6.31 \mathrm{~cm}^{2}$ of leaf $/ \mathrm{cm}^{2}$ of soil. At the lowest maize plant density, an effect of the Urochloa plant densities was observed, with the curve being fitted to a quadratic equation, with greater value in the growing of maize alone, showing a light reduction and then with an increase in values, as increased the Urochloa plant density. Lower plant densities of Urochloa presented more tillering, and this may compete with maize leading to reduce maize LAI. As forage with less developed per plant (in its higher density) can stimulate the maize LAI (Figure 2 and 7).

The lack of difference in the lowest maize plant density may be attributed to less competition among plants for environmental resources in the same space at the greater plant density, where a considerable number of senescent leaves was observed soon after flowering of the maize in the intercropped treatments, indicating high demand for photoassimilates in the grain filling period (Argenta et al., 2001a). Grain yield is a function of canopy photosynthesis and transpiration which, for its part, is dependent on solar radiation interception and on the quality of incident radiation (Floss, 2011).

The total chlorophyll and chlorophyll A content have greater reduction from 14 to 28 days after the beginning of flowering, which may be due to grain filling, and the ear being a strong photoassimilate drain (Figure 3). The Urochloa plant density expressed a quadratic equation to represent the chlorophyll index in the maize leaves (Figure 4). Chlorophyll A and total chlorophyll are extremely important because the chlorophyll content in the leaf may be used to determine the nutritional level of nitrogen in the plant since the quantity of this pigment is correlated in a positive way with nitrogen content (Rambo et al., 2011).
When grain filling intensifies, there is displacement of plant reserves to the ear, reducing the chlorophyll index in the leaves, which stabilizes upon completing grain filling, leading to leaf senescence, with translocation of organic matter (Loomis et al., 1971; Argenta et al., 2001b). In relation to plant density of the forage crop, in the lowest plant densities, a greater decrease of the total chlorophyll index occurred than a decrease of chlorophyl A; nevertheless, at the greatest plant densities, the reduction was lower in both, indicating that above 20 plants $\mathrm{m}^{-2}$, interspecific competition is reduced (Sereia et al., 2011).

The CGR at lower maize plant density decreases as a function of the Urochloa plant densities, stabilizing at a density of 10 plants $\mathrm{m}^{-2}$. This may be due to the compensation capacity of forage for dry matter production, even in stress periods, as in the case of high competition (Argenta et al., 2001a; Sangoi et al., 2002; Argenta et al., 2003; Afférri et al., 2008). Thus, high maize plant densities have greater performance in intercropping due to greater shading and greater competition with the forage crop (Figure 5).

The GFR of the maize was not affected by the Urochloa plant densities at its lowest plant density, having shown a mean value of $71.55 \mathrm{~kg}$ day $\mathrm{ha}^{-2}$. At the greatest plant density, the GFR was best represented by a quadratic equation, with reduction up to 20 plants $\mathrm{m}^{-2}$ and an increase at the greatest plant density (Figure 5). Interspecific competition may be reducing the competition with maize, or stimulating it to greater production; but on the other hand, at the density of 20 plants $\mathrm{m}^{-2}$, there may have been greater growth of the forage crop at the beginning and then it causes greater competition with the maize. The GFR shows the speed at which 


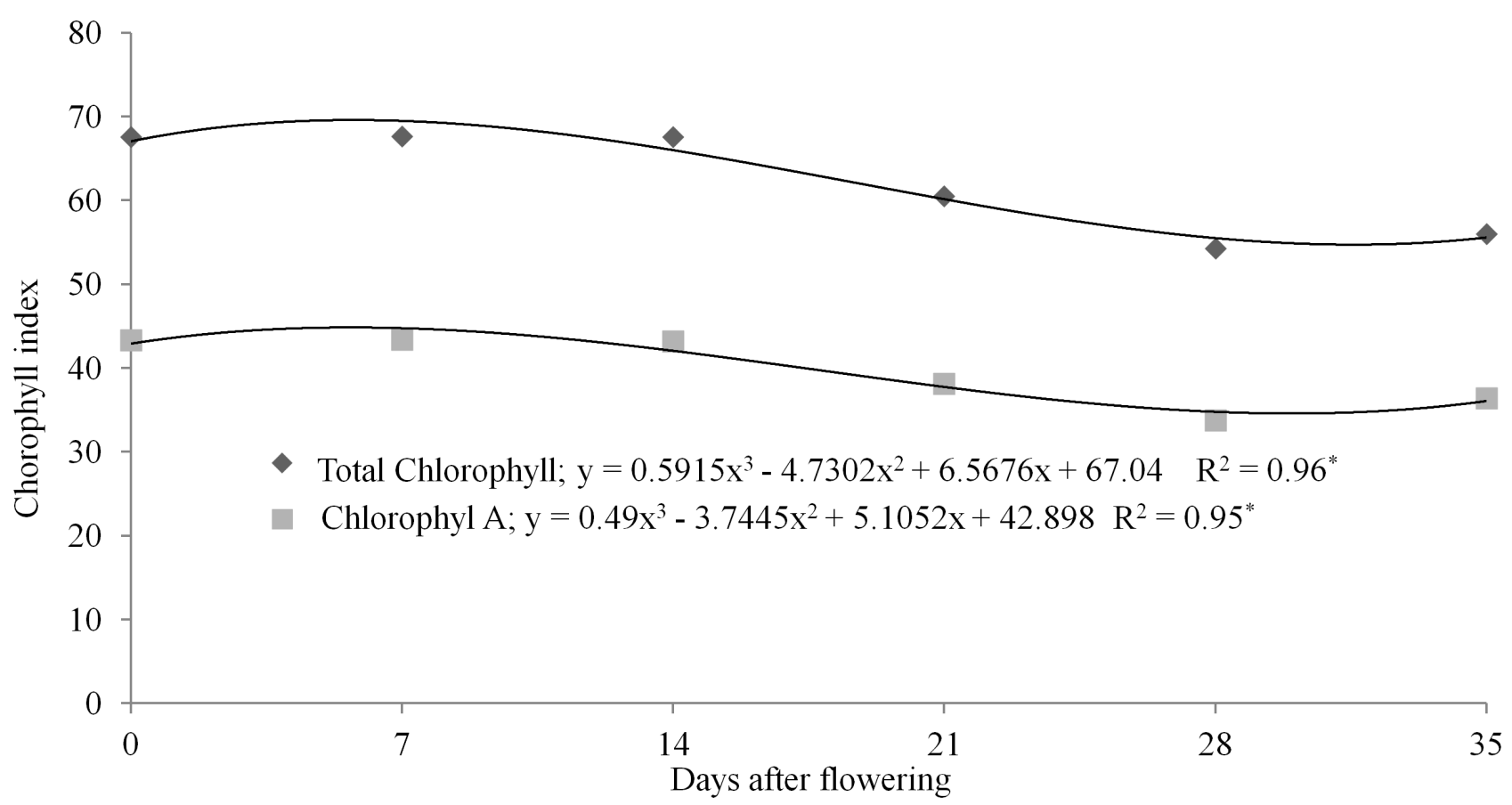

FIGURE 3. Chlorophyll index in the maize leaves (means of two densities) as a function of the time in Dourados, MS, Brazil, 2012.

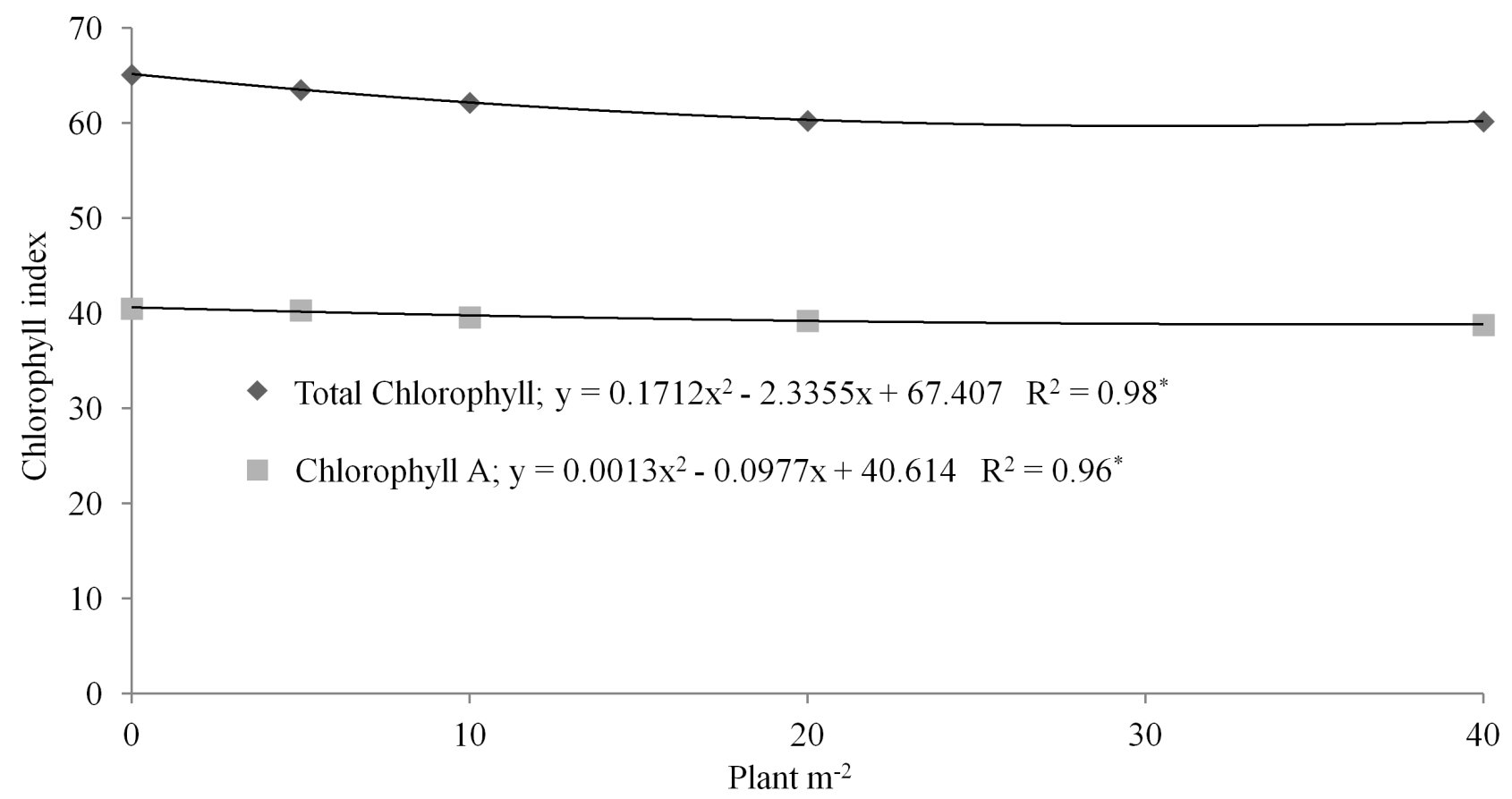

FIGURE 4. Chlorophyll index in maize leaves (means of two densities) as a function of the forage crop plant density in Dourados, MS, Brazil, 2012. 


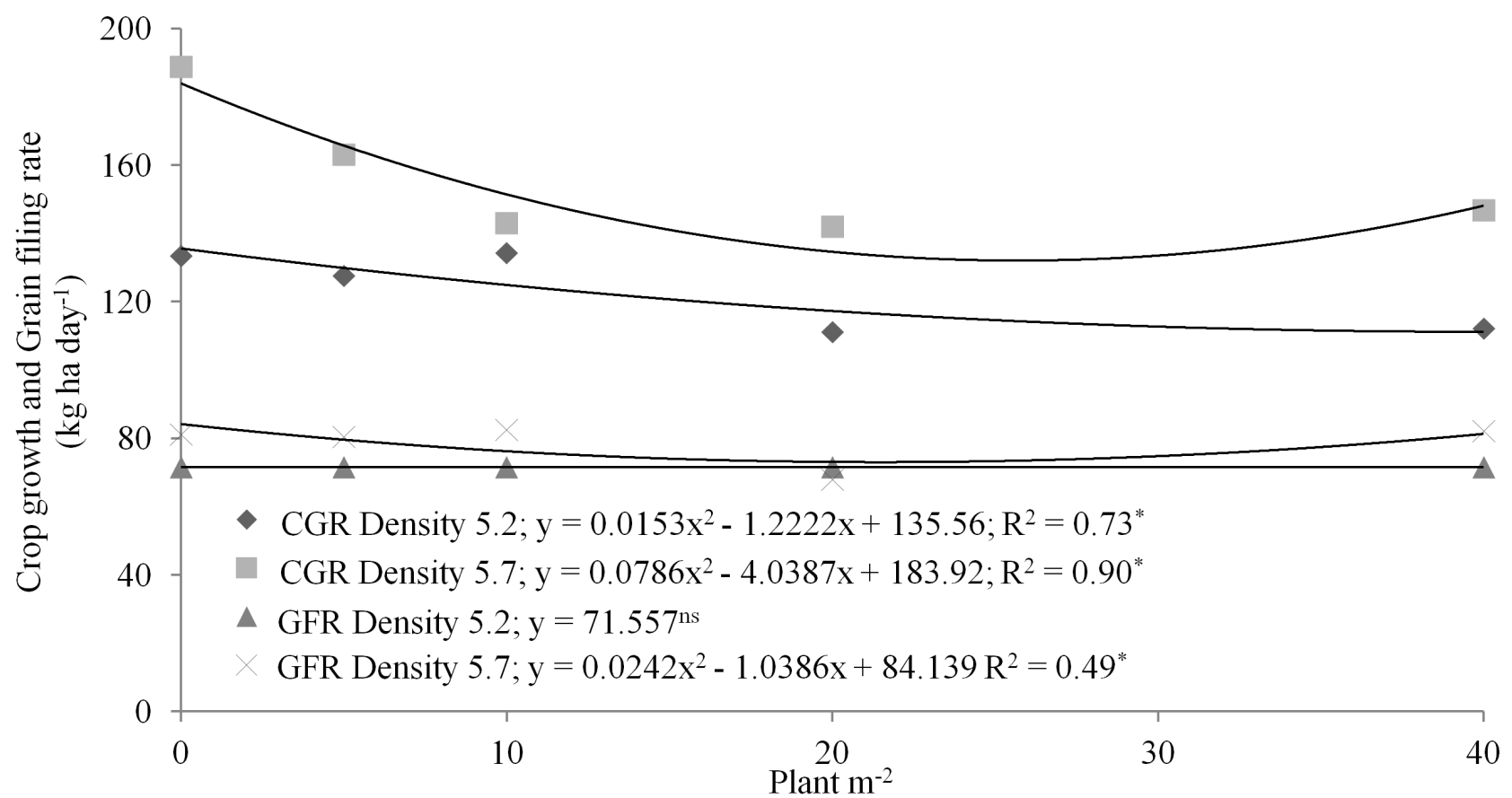

FIGURE 5. Crop growth rate (CGR) and Grain filling rate (GFR) (kg day ha ${ }^{-2}$ ) of maize at two plant densities (5.2 and 5.7 plants $\mathrm{m}^{-2}$ ) alone and intercropped with different plant densities of Urochloa brizantha 'Marandu' in Dourados, MS, Brazil, 2012.

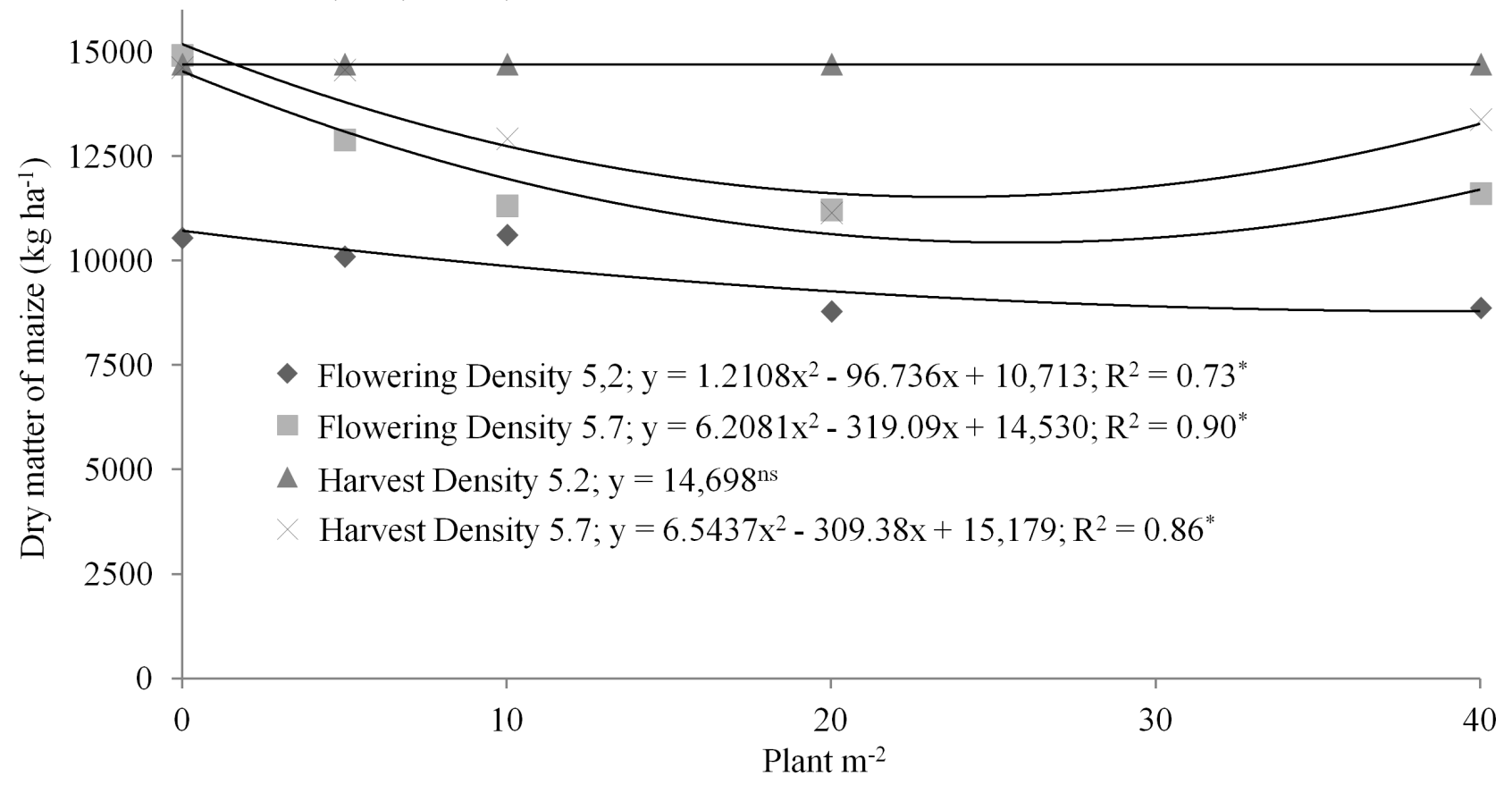

FIGURE 6. Dry matter yield of maize at flowering and at harvest at two plant densities of maize (plants $\left.\mathrm{m}^{-2}\right)$ with five plant densities of Urochloa brizantha 'Marandu' $\left(0,5,10,20\right.$ and 40 plants $\left.\mathrm{m}^{-2}\right)$ in Dourados, MS, Brazil, 2012. 


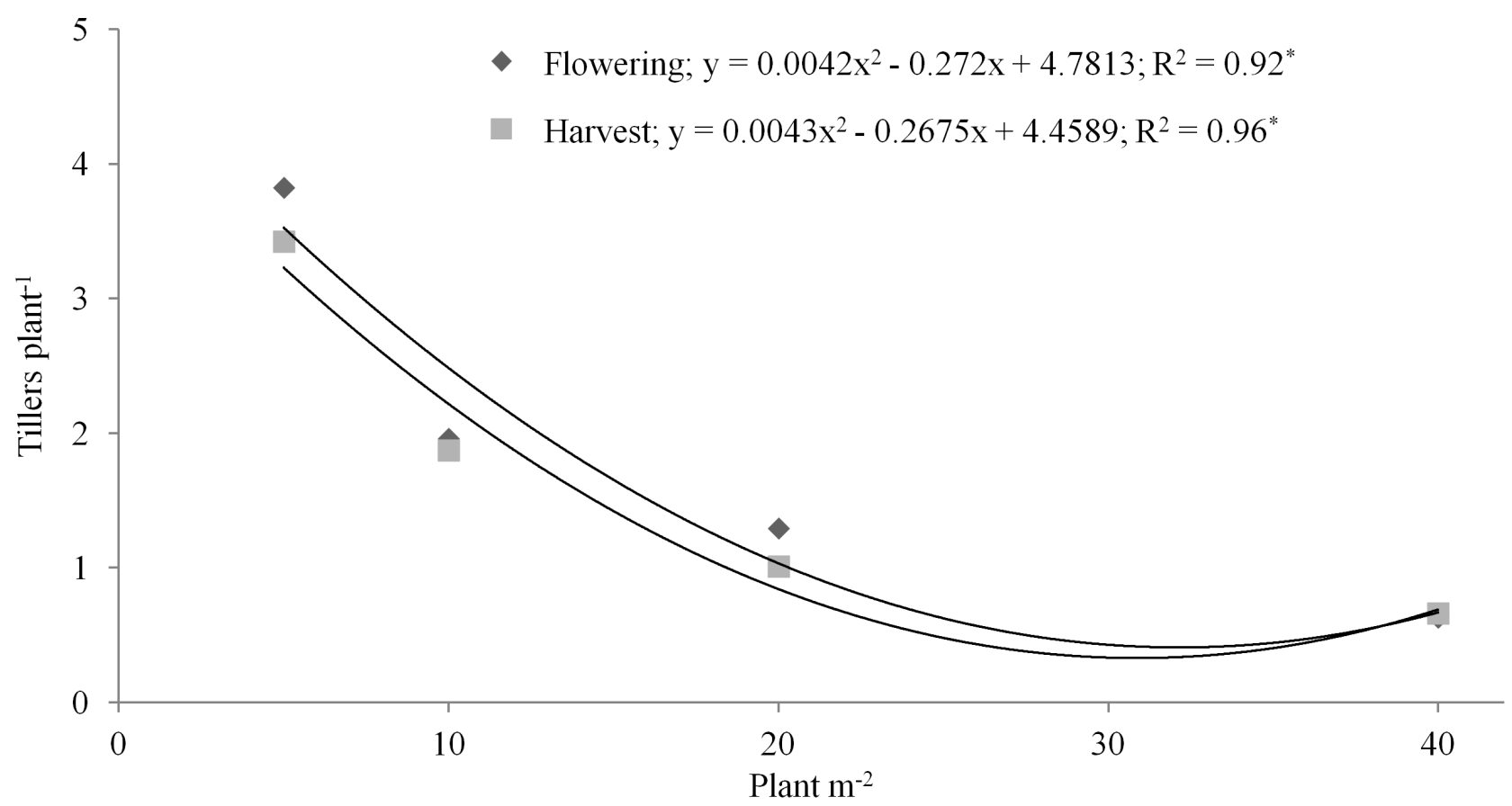

FIGURE 7. Tillering per plant of Urochloa brizantha cv. 'Marandu' (means of two densities) as a function of its plant density $\left(0,5,10,20\right.$ and 40 plants $\left.\mathrm{m}^{-2}\right)$ at maize flowering and harvest, intercropped with maize in Dourados, MS, Brazil, 2012.

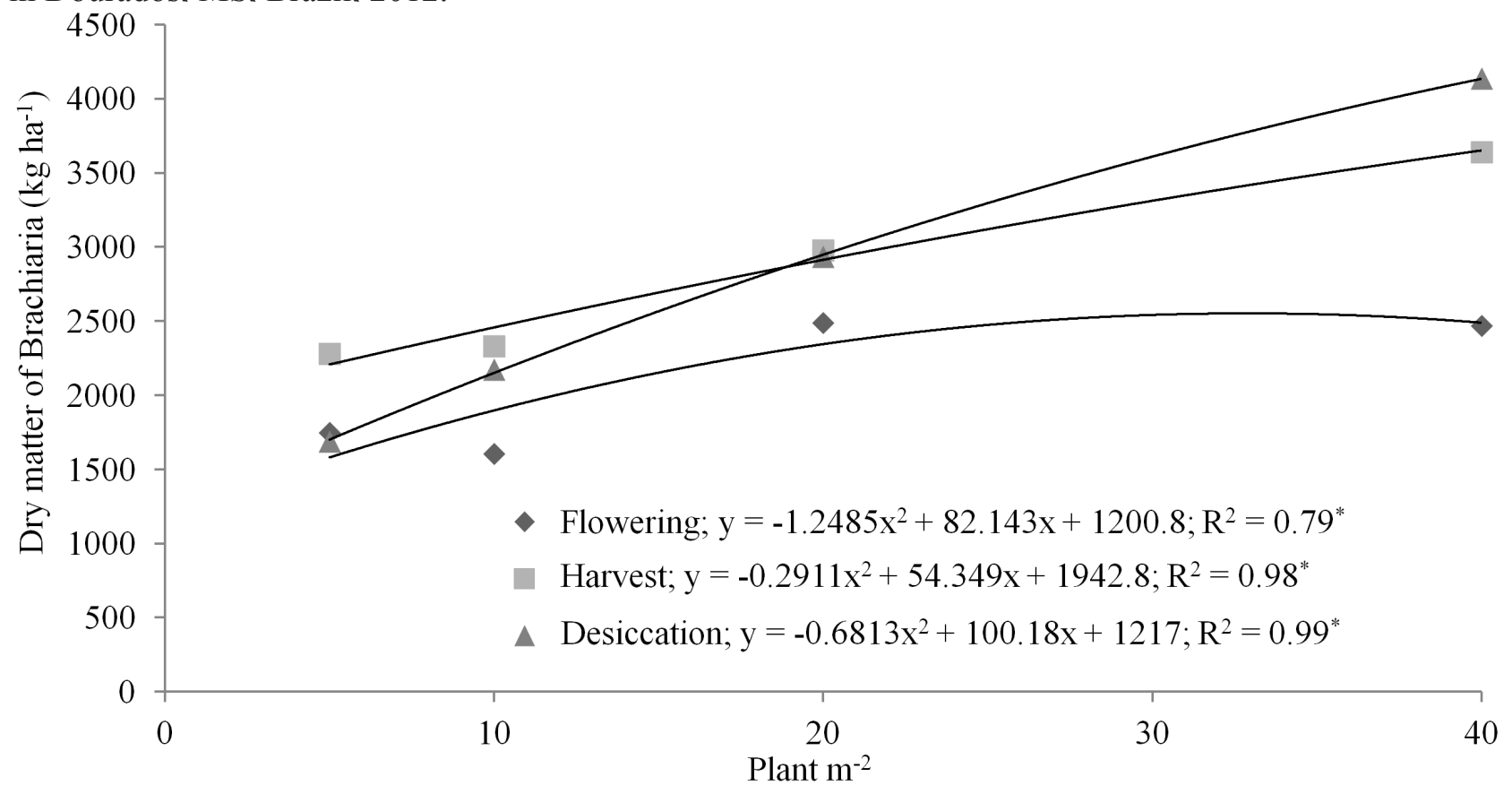

FIGURE 8. Dry matter yield of Urochloa brizantha 'Marandu' at maize flowering and harvest, and at desiccation. Mean value of the two maize plant densities (5.2 and 5.7 plants $\mathrm{m}^{-2}$ ) in Dourados, MS, Brazil, 2012 . 
the plants accumulate plant matter in the grains, and the participation of each plant leads to a greater rate at the greater plant density (Figure 5). According to Argenta et al. (2003), the environment affects grain accumulation, whereas good crop management may collaborate so that plants show genetic potential.

The dry matter yield of maize at flowering was higher at greater plant density (Table 1), and was affected by the Urochloa plant densities (Figure 5). Nevertheless, during grain filling, there was compensation in plant matter yield at the lower plant density, whereas at the greater plant density there was maintenance of the accumulated matter, maintaining the effect of the Urochloa plant densities only in the greater plant density.

The yield of maize dry matter was higher at flowering in the greater plant density (Table 1), and both densities were influenced by Urochloa plant densities. However, during the grain filling, there was higher accumulation of mass in leaf and stem, no effect of Urochloa plant densities. Maize bulk density accumulated in leaf and stem dry matter was little, and higher in grains, resulting in a higher productivity while maintaining Urochloa plant densities effect (Figure 6). According to Vargas et al. (2011), maize plants sensitivity is related to competition with any other plant in the same living space, which explains the reduction in dry matter accumulation in intercropped treatments.

Tillering represents the quantity of tillers in relation to the number of plants and indicates the ability of the plant to put forth tillers. There was not observed any difference among the maize densities at flowering and at harvest (Figure 7). This may be due to the fact of maize having more rapid initial growth than the forage crop (Sereia et al., 2012). Between maize flowering and harvest there are no differences once there is low light. Therefore, when there is maize harvest and there is a light in, the greater Urochloa plant densities provide greater capacity for plant mass yield for establishment of pasture, and integrate with livestock raising through having a greater quantity of plants in relation to the spaces, as reported by Portes et al. (2000).

Tillering of forage grasses is regulated by light incidence and temperature, which regulate the ratio of the auxin of the above ground part and the cytokinin of the roots. However, when there is not a greater light in, there is competition for space and, in this case, lower plant densities may exhibit greater tillering (Lamaire \& Chapman, 1996). The greater the quantity of light and temperature the plants receive, the greater the tillering. Consequently there is lower plant development reasoned to low light in, as already said Vieira (1985) in the case of maize and beans intercropping.

The increase in the maize plant density did not affect the quantity of plant matter produced by U. brizantha cv. 'Marandu' (Figure 8), but according to Lamaire \& Chapman (1996), shading reduces dry matter through less tillering. This growth may have been made uniform by the period of greater light in after senescence of the leaves, allowing greater growth of the forage crop, even at lower plant densities. In the evaluation made in September 2012, greater plant matter yield was observed at the greater plant density of Urochloa (Figure 8), even though it was a period of low water availability. Upon maize harvest, there was light stimulation for putting forth new tillers and an increase in dry matter (Sereia et al., 2012) since forage growth is more affected by environmental conditions, such as water availability and temperature, than thermal time (Sbrissia, 2004). 


\section{Conclusions}

The increase in the maize plant density increases the leaf area index and the yield of late season maize, but does not affect the maize chlorophyll index and dry matter yield of $U$. brizantha cv. 'Marandu'.

The plant densities of intercropped $U$. brizantha $\mathrm{cv}$. 'Marandu' do not significantly reduce maize yield, with the lowest plant densities being recommended for straw production.

Plant densities of 20 plants $\mathrm{m}^{-2}$ or more of $U$. brizantha cv. 'Marandu' lead to a satisfactory density of stems and increase dry matter accumulation of the forage crop. Thus, they may be recommended for pasture formation for integration with livestock raising.

\section{Acknowledgements}

The authors acknowledge the National Council for Scientific and Technological Development, CNPq, for providing financial support and Stella M. Faquer for the assistance in the translations.

\section{References}

AFFÉRRI, F. S.; MARTINS, E. P.; PELUZIO, J. M.; FIDELIS, R. R.; RODRIGUES, H. V. M. Espaçamento e densidade de semeadura para a cultura do milho, em plantio tardio, no estado do Tocantins. Pesquisa Agropecuária Tropical, Goiânia, v. 38, n. 2, p. 128-133, 2008.

ARGENTA, G.; SANGOI, L.; SILVA, P. R. F.; RAMPAZZO, C.; GRACIETTI, L. C.;
STRIEDER, M. L.; FORSTHOFER, E. L.; SUHRE, E. Potencial de rendimento de grãos de milho em dois ambientes e cinco sistemas de produção. Scientia Agraria, Curitiba, v. 4, n. 1-2, p. 27-34, 2003.

ARGENTA, G.; SILVA, P. R. F.; BORTOLINI, C. G. Teor de clorofila na folha como indicador do nível de nitrogênio em cereais. Ciência Rural, Santa Maria, v. 31, n. 4, p. 715-722, 2001b.

ARGENTA, G.; SILVA, P. R. F.; SANGOI, L. Arranjo de plantas em milho: análise do estado-da-arte. Ciência Rural, Santa Maria, v. 31, n. 6, p. 1075-1084, 2001a.

BORGHI, E.; CRUSCIOL, C. A. C. Produtividade de milho, espaçamento e modalidade de consorciação com Brachiaria brizantha em sistema plantio direto. Pesquisa Agropecuária Brasileira, Brasília, DF, v. 42, n. 2, p. 163-171, 2007.

BRASIL. Ministério da Agricultura e Reforma Agrária. Regras para análise de sementes. Brasília, DF: SNDA/DNDV/CLAV, 2009. $365 \mathrm{p}$.

CECCON, G. Cerrado: Estado da arte na produção de palha com milho safrinha em consórcio com Brachiaria. Revista Plantio Direto, Passo Fundo, v. 17, n. 102, p. 3-7, 2007.

CECCON, G.; STAUT, L. A.; SAGRILO, E.; MACHADO, L. A. NUNES, D. P.; ALVES, V. B. Legumes and forage species sole or intercropped with corn in soybean-corn succession in Midwestern Brazil. Revista Brasileira de Ciência do Solo, Viçosa, MG, v. 37, p. 204-212, 2013.

CHIODEROLI, C. A.; MELO, L. M. M.; GRIGOLLI, P. J.; SILVA, J. O. R.; CESARIN, 
A. L. Consorciação de braquiárias com milho outonal em plantio direto sob pivô central. Revista Brasileira de Engenharia Agrícola e Ambiental, Campina Grande, v. 30, n. 6, p. 1101-1109, 2010.

EMBRAPA AGROPECUÁRIA OESTE. Clima

MS: banco de dados. Dourados, 2013.

Disponivel em: <http://www.cpao.embrapa. br/clima/> Acesso em: 14 abr. 2013.

FALKER. CFL 1030 - Medidor eletrônico de teor de clorofila - clorofiLOG. Disponivel em: $\quad<$ http://www.falker.com.br/Produto. php?id=4 > Acesso em: 16 jun. 2012.

FIETZ, R. C.; FISCH, G. F. O clima da região de Dourados, MS. Dourados: Embrapa Agropecuária Oeste, 2008. 32 p. (Embrapa Agropecuária Oeste. Documentos, 92).

FLOSS, E. L. Fisiologia das plantas cultivadas. 5 ed. Passo Fundo: UPF, 2011. 734 p.

IKEDA, F. S. Interação entre as culturas de soja e milho com cultivares do gênero Urochloa $P$. Beauv. em consórcio e interferência de plantas daninhas nos sistemas. 2010. 162 f. Tese (Doutorado em Ciências) - Escola Superior de Agricultura Luiz de Queiroz, Universidade de São Paulo, Piracicaba.

KLUTHCOUSKI, J.; COBUCCI, T.; AIDAR, H.; YOKOYAMA, L. P.; OLIVEIRA, I. P.; COSTA, J. L. S.; VILELA, L.; BARCELLOS, A. O.; MAGNABOSCO, C. U. Sistema Santa Fé - Tecnologia Embrapa: integração lavoura-pecuária pelo consórcio de culturas anuais com forrageiras, em áreas de lavoura, nos sistemas direto e convencional. Santo Antônio de Goiás: Embrapa Arroz e Feijão, 2000. 28 p. (Embrapa Arroz e Feijão. Circular técnica, 38).
LAMAIRE, G.; CHAPMAN, D. Tissue flows in grazed plant communities. In: HODGSON, J.; OLLiUS, A.W. (Ed.). The ecology and management of grazing systems. London: CAB International, 1996. cap. 1, p. 3-36.

LOOMIS, R. S.; WILLIAMS, W. A.; HALL, A. E. Agricultural productivity. Annual Review of Plant Physiology, Palo Alto, v. 22, p. 431-468, 1971.

PORTES, T. A.; CARVALHO, S. I. C.; OLIVEIRA, I. P.; KLUTHCOUSKI, J. Análise do crescimento de uma cultivar de braquiária em cultivo solteiro e consorciado com cereais. Pesquisa Agropecuária Brasileira, Brasília, DF, v. 35, n. 7, p. 1349-1358, 2000. RAMBO, L.; SILVA, P. R. F.; STRIEDER, M. L.; SILVA, A. A.; SANGOI, L.; VIEIRA, V. M. Índices nutricionais de $\mathrm{N}$ e produtividade de milho em diferentes níveis de manejo e de adubação nitrogenada. Pesquisa Agropecuária Brasileira, Brasília, DF, v. 46, n. 4, p. 390-397, 2011.

RESENDE, S. G.; PINHO, R. G. V.; VASCONCELOS, R. D. Influência do espaçamento entre linhas e da densidade de plantio no desempenho de cultivares de milho. Revista Brasileira de Milho e Sorgo, Sete Lagoas, v. 2, p. 34-42, 2003.

SANGOI, L.; ALMEIDA, M. L.; SILVA, P. R. F.; ARGENTA, G. Bases morfofisiológicas para maior tolerância dos híbridos modernos de milho a altas densidades de plantas. Bragantia, Campinas, v. 61, p. 101-110, 2002.

SBRISSIA, A. F. Morfogênese, dinâmica do perfilhamento e do acúmulo de forragem em pastos de capim-Marandu submetidos a regimes de lotação contínua. 2004. 171 
f. Tese (Doutorado em Ciência Animal e Pastagens) - Universidade de São Paulo, Piracicaba.

SEREIA, R. C.; CECCON, G.; PADILHA, N. S.; ALVES, V. B.; LEITE, L. F.; SOARES, R. B. Índice de clorofila em miho safrinha sob diferentes modalidades de cultivo. In: SEMINÁRIO NACIONAL DE MILHO SAFRINHA, 11, 2011, Lucas do Rio Verde. De safrinha a grande safra: anais. Lucas do Rio Verde: Fundação Rio Verde: ABMS, 2011. p. 123-131.

SEREIA, R. C.; LEITE, L. F.; ALVES, V. B.; CECCON, G. Crescimento de Brachiaria spp. e milho safrinha em cultivo consorciado. Agrarian, Dourados, v. 5, n. 18, p. 349-355, 2012.

SISTEMA Brasileiro de Classificação de Solos. Brasília, DF: Embrapa Produção de
Informação; Rio de Janeiro: Embrapa Solos, 1999. $412 \mathrm{p}$.

VARGAS, L.; PEIXOTO, C. M.; ROMAN E, S. Manejo de plantas daninhas na cultura do milho. Passo Fundo: Embrapa Trigo, 2006. 20 p. ((Embrapa Trigo. Documentos Online, 61).). Disponivel em: <http://www.cnpt. embrapa.br/biblio/do/p_do61.htm>. Acesso em: 19 mar. 2011.

VIEIRA, C. O feijão em cultivos consorciados. Viçosa, MG: Universidade Federal de Viçosa, 1985. 134 p.

VILELA, L.; MARTHA JUNIOR, G. B.; MACEDO, M. C. M.; MARCHÃO, R. L.; GUIMARÃES JÚNIOR, R.; PULROLNIK, K.; MACIEL, G. A. Sistemas de integração lavoura-pecuária na região do Cerrado. Pesquisa Agropecuária Brasileira, Brasília, DF, v. 46, n. 10, p. 11271138, 2011. 